DOI: $10.33766 / 2524-0323.92 .273-285$

УДК 343.6

О. А. Трегуб,

кандидат юридичних наук, молодший науковий співробітник відділу господарсько-правових досліджень проблем економічної безпеки Інституту економіко-правових досліджень імені В. К. Мамутова НАН України (м. Київ, Україна) e-mail: alexandr.fispeam@gmail.com iDhttps://orcid.org/0000-0003-0660-5783

\title{
ПРАВОВЕ ЗАБЕЗПЕЧЕННЯ ЕКОЛОГІЧНОГО ВІДНОВЛЕННЯ МІСТ НА ПОСТКОНФЛІКТНИХ ТЕРИТОРІЯХ
}

Стаття присвячена обгрунтуванню пропозицій щодо вдосконалення правового забезпечення екологічного відновлення міст на постконфліктних територіях. Для зменшення обсягів накопичення на цих територіях небезпечних відходів витрати на їх перевезення до місць утилізації запропоновано тимчасово фінансувати за рахунок бюджетних коштів. Аргументовано, що застосування принципу наближеності до джерел утворення відходів потребує обмеження щодо зон, які прилягають до лінії розмежування та перебувають під загрозою ураження внаслідок бойових дій. Запропоновано визначити особливості моніторингу довкілля на постконфліктних територіях із використанням космічних технологій.

Ключові слова: відновлення, постконфліктні території, екологічна безпека, відходи, моніторинг довкілля, космічні технології.

Постановка проблеми. Збройний конфлікт на сході України призвів до стрімкого погіршення екологічної ситуації, яка й до початку бойових дій вирізнялася надзвичайною гостротою і складністю. Традиційно високе навантаження на всі компоненти навколишнього середовища та здоров'я населення збільшилося унаслідок безпосереднього впливу військових дій (хімічне забруднення від використання боєприпасів, військової техніки і т. ін.), пошкодження екологічно небезпечних об'єктів, зупинення діяльності багатьох промислових підприємств, соціальної кризи та застосовування тимчасових заходів (мораторій на здійснення державного контролю у сфері господарської діяльності, продовження дії документів дозвільного характеру й ін.). Через це негативний екологічний стан території Донецької і Луганської областей визнається однією 3 ключових загроз національній безпеці України (Стратегія національної безпеки України «Безпека людини - безпека країни», затверджена Указом Президента України від 14.09 .2020 р. № 392/2020) [1].

Конституція України покладає на державу обов'язок із забезпечення екологічної безпеки і підтримання екологічної рівноваги на території України (ст. 16), тоді як за кожною людиною визнає право на проживання в безпечному для іï життя і здоров'я довкіллі (ст. 50) [2]. На постконфліктних територіях реалізація цих конституційних норм набуває особливої значущості та потребує додаткових зу-

() Трегуб О. А., 2020 
силь і спеціальних підходів. Необхідно спиратися на те, що питання охорони навколишнього природного середовища та використання природних ресурсів мають вирішуватися з огляду на ступінь антропогенної зміненості територій та сукупну дію факторів, що негативно впливають на екологічну обстановку. А екологічні права забезпечуються проведенням широкомасштабних державних заходів щодо підтримання, відновлення і поліпшення стану довкілля (ст.ст. 3, 10 Закону України від 25.06.1991 р. № 1264-XII «Про охорону навколишнього природного середовища») [3].

Наведені положення закону враховуються в постанові Верховної Ради України від 14.01.2020 р. «Про Рекомендації парламентських слухань на тему: «Пріоритети екологічної політики Верховної Ради України на наступні п'ять років», яка рекомендує Міністерству з питань реінтеграції тимчасово окупованих територій України спільно з Міністерством захисту довкілля та природних ресурсів України розглянути питання щодо екологічного відновлення Донбасу та запропонувати законодавчі шляхи його вирішення [4]. Виконання цього завдання сприятиме покращенню екологічних умов проживання в містах як соціальних, економічних, культурних і політичних центрах регіону.

Аналіз останніх досліджень і публікацій. Проблематиці відновлення екологічної рівноваги та поліпшення екологічної ситуації на постконфліктних територіях юридична наука не приділяє належної уваги. Серед нечисленних досліджень варто виокремити статтю І. О. Личенка «Проблеми екологічної безпеки тимчасово окупованих територій Донецької та Луганської областей та організаційно-правові засади їхнього вирішення» (2016р.), у якій пропонуються заходи 3 підвищення ефективності правової політики держави щодо вирішення екологічних проблем Донбасу. Зокрема, автор вважає за доцільне виділити в структурі Міністерства екології та природних ресурсів України підрозділ, основним призначенням якого має бути формування системи заходів протидії екологічним загрозам військових дій у вказаному регіоні [5, с. 283]. Окремі правові аспекти відповідної проблематики висвітлюються також у працях В. А. Устименка і Р. А. Джабраілова (розглядаються особливості реалізації інвестиційних екологічних проєктів у Донецькій і Луганській областях на засадах публічно-приватного партнерства, 2019 р.) [6, с. 18-19], О. Р. Зельдіної (пропонується запровадити спеціальний режим господарювання для створення екологічно безпечних умов розвитку Донбасу, 2019 р.) [7, с. 25-33] та О. Ю. Ілларіонова (визначаються перспективи нормативного забезпечення ліквідації надзвичайних ситуацій на територіях затоплених вугільних шахт, 2019 р.) [8, с. 82-86].

Водночас залишається низка важливих питань правового забезпечення екологічного відновлення міст на постконфліктних територіях, подальше дослідження яких є актуальним. Зокрема, до них належать правові питання, що стосуються специфіки поводження 3 відходами та здійснення екологічного моніторингу на відповідних територіях.

Формулювання цілей. Метою цієї статті є обгрунтування пропозицій щодо вдосконалення правового забезпечення екологічного відновлення міст на постконфліктних територіях. 
Виклад основного матеріалу. Нинішня екологічна ситуація на постконфліктних територіях характеризується виникненням нових та загостренням наявних екологічних загроз. Як випливає із Закону України від 28.02.2019 р. № 2697-VIII «Про Основні засади (стратегію) державної екологічної політики України на період до 2030 року» та Звіту про стратегічну екологічну оцінку Державної програми розвитку транскордонного співробітнищтва на 2021-2027 роки, основними загрозами для навколишнього середовища, життя і здоров'я мешканців Донецької і Луганської областей є: затоплення шахт та можливість виходу токсичних шахтних вод на поверхню, проникнення в підземні води, а також потрапляння їх до річки Сіверський Донець та Азовського моря; підтоплення територій шахтними водами та руйнування будинків і споруд у межах територій, наближених до виведених із експлуатації шахт; забруднення водних ресурсів унаслідок руйнування інфраструктури, що забезпечує водопостачання; припинення роботи очисних споруд та пошкодження сховищ токсичних і радіоактивних відходів; пошкодження територій та об'єктів природно-заповідного фонду; забруднення атмосферного повітря та грунтів хімічними продуктами внаслідок вибухів боєприпасів; знищення ландшафтів і рослинності у зв'язку з використанням військової техніки та будівництвом оборонних споруд; знищення значних площ лісів через пожежі та неконтрольовані рубки [9; 10, с. 33].

У публікації ОБСС «Оцінка екологічної шкоди та пріоритети відновлення довкілля на сході України» (2017р.) зазначається, що особливою загрозою є підтоплення тих шахт, які використовувалися для зберігання небезпечних відходів (шахти «Олександр-Захід», «Вуглегірська» Донецької області), а також шахти «Юний комунар». У 1979 р. у цій шахті проводився підземний ядерний вибух, після якого на глибині залишилася радіоактивно забруднена вода. Припинення водовідливу з шахт загрожує підтопленням територій і просіданням їх поверхні, виведенням із експлуатації об'єктів інфраструктури, у т.ч. підземні газопроводи, каналізаційні та водопровідні системи [11, с. 12]. Уже в червні 2018 р. Міністерство 3 питань тимчасово окупованих територій та внутрішньо переміщених осіб України повідомило, що поверхня міста Донецька осіла на глибину від 20 до 25 см (за даними космічних зйомок) [12].

Ситуація в містах на постконфліктних територіях ускладнюється тим, що нерозв'язані екологічні проблеми негативно впливають на інші показники якості життя, оскільки обмежують можливості економічного розвитку та стримують споживання матеріальних благ, знижують рівень охорони здоров'я в умовах мутації небезпечних вірусів та збудників інфекційних захворювань [13, с. 76]. Отже, стабілізація та покращення екологічної обстановки в цих містах мають бути завданням екологічної політики на всіх їі рівнях, а саме: національному, регіональному, місцевому та об' єктовому (локальному). Участь кожного рівня залежить від його призначення та можливостей (організаційних, фінансових, технологічних та ін.).

У національному (загальнодержавному) масштабі до екологічних проблем постконфліктних територій дотичні: Закон України «Про Основні засади (стратегію) державної екологічної політики України на період до 2030 року», постанови Кабінету Міністрів України від 05.08.2020 р. № 695 «Про затвердження Державної 
стратегії регіонального розвитку на 2021-2027 роки», від 13.12.2017 р. № 1071 «Про затвердження Державної цільової програми відновлення та розбудови миру в східних регіонах України», а також інші документи державного планування.

Так досягнення мети Державної цільової програми відновлення та розбудови миру в східних регіонах України має здійснюватися шляхом виконання програмних заходів із відновлення критичної інфраструктури та основних соціальних послуг у таких сферах, як: освіта, охорона здоров'я, соціальний захист, об'єкти соціальної інфраструктури, енергетика, транспорт, водопостачання та водовідведення, екологія та охорона навколишнього природного середовища. У сферах «Водопостачання та водовідведення» $\mathrm{i}$ «Екологія та охорона навколишнього природного середовища» Програма передбачає виконання декількох екологічних заходів, а саме: ремонт п'яти свердловин; побудову та реконструкцію чотирьох полігонів твердих побутових відходів; зведення одного сміттепереробного заводу; очищення 0,5 км берегів р. Айдар, 36,7 км берегів р. Казенний Торець та 78,8 км берегів р. Бахмутка [14]. Отже, відповідна Програма не передбачає комплексного підходу до екологічного оздоровлення східних регіонів та орієнтована на розв'язання «точкових» екологічних проблем. За змістом та питомою вагою запланованих заходів цей документ здебільшого спрямований на вирішення соціально-економічних завдань, а його екологічні цілі є другорядними.

Посилити національний рівень політики щодо екологічного відновлення міст на постконфліктних територіях можливо шляхом виконання постанови Верховної Ради України «Про Рекомендації парламентських слухань на тему: «Пріоритети екологічної політики Верховної Ради України на наступні п'ять років». Ця Постанова рекомендує Кабінету Міністрів України прискорити розроблення та затвердження комплексної програми стабілізації екологічної ситуації та забезпечення екологічної безпеки на Донбасі [4]. У перспективі така програма стане основою для реалізації взаємопов'язаних заходів і завдань, спрямованих на розв'язання найважливіших екологічних проблем відповідних територій.

Велику роль притому відіграє й здійснення регіональної екологічної політики, особливості та пріоритети якої відбиті в екологічних програмах і планах відповідного рівня.

Наприклад, у Донецькій області діють такі екологічні програми і плани: План дій з охорони навколишнього природного середовища Донецької області на 20132020 роки, затверджений рішенням Донецької обласної ради від 30.05.2013 p. № 6/21-509; Програма поводження 3 відходами в Донецькій області на 20162020 роки, затверджена розпорядженням голови Донецької обласної державної адміністрації від 22.09.2016 р. № 836; Програма «Чисте повітря Донеччини на 20182020 роки та прогноз до 2030 року», затверджена розпорядженням голови Донецької обласної державної адміністрації від 28.12.2018 р. № 1571/5-18; Регіональна програма моніторингу стану довкілля в Донецькій області, затверджена розпорядженням голови Донецької обласної державної адміністрації від 13.01.2020 р. № 20/5-20; а також низка інших програм та планів.

Досягненням регіональної екологічної політики Донецької області можна вважати впровадження першої в Україні автоматизованої системи екологічного 
моніторингу, яка містить у складі 6 підсистем: моніторинг атмосферного повітря, поверхневих вод, морської води, грунтів, підземних вод та зелених насаджень [15].

Однак, незважаючи на певні здобутки, у цілому ефективність екологічної політики щодо постконфліктних територій є доволі низькою. Стійким чинником погіршення екологічної обстановки в містах на цих територіях є накопичення великої кількості небезпечних промислових відходів. У Регіональній доповіді про стан навколишнього природного середовища в Луганській області у 2018 р. наголошується, що в регіоні майже повністю відсутні підприємства, які мають ліцензію на здійснення операцій у сфері поводження з небезпечними відходами. При укладенні договорів на передачу цих відходів спеціалізованим підприємствам інших областей транспортні витрати на перевезення подекуди перевищують вартість самої утилізації утворених відходів [16]. На кінець 2018 р. у спеціально відведених місцях та об'єктах на території Луганської області накопичилося 859,3 тис. тонн відходів I-ІІІ класів небезпеки [17], що є одним із найвищих показників в Україні.

Тимчасовим виходом із цієї ситуації може бути покриття витрат на перевезення небезпечних відходів за рахунок бюджетних коштів. Так п.«г» ч.1 ст. 40 Закону України від 05.03.1998 р. № 187/98-ВР «Про відходи» передбачає такий захід стимулювання утилізації відходів, як дотації з Державного бюджету України і місцевих бюджетів для їх перевезення [18]. Забезпечення екологічно безпечного перевезення відходів є природоохоронним заходом відповідно до п.74-1 постанови Кабінету Міністрів України від 17.09.1996 р. № 1147 «Про затвердження переліку видів діяльності, що належать до природоохоронних заходів» [19]. Використання бюджетних коштів на природоохоронні заходи здійснюється в порядку, що визначається наказом Міністерства екології та природних ресурсів України від 12.06.2015 р. № 194 «Про затвердження Порядку планування та фінансування природоохоронних заходів» (для Державного бюджету України) та рішеннями органів місцевого самоврядування (для місцевих бюджетів). Умовами покладення витрат на перевезення небезпечних відходів знову на їх власників (згідно з еколого-правовим принципом «забруднювач сплачує») є покращення їх фінансового становища та створення достатніх регіональних потужностей з утилізації таких відходів.

Ризики, пов' язані з військовими діями на сході України, не можуть бути проігноровані в процесі адаптації законодавства про відходи до права ЄС. Угода про асоціацію з СС зобов'язує Україну наблизити своє законодавство до Директиви 2008/98/СС про відходи, що є стрижневим нормативно-правовим актом Співтовариства у сфері поводження з відходами. У ст.16 цієї Директиви закріплено принцип наближеності, згідно з яким видалення та утилізація відходів мають відбуватися якомога ближче до джерел їх утворення для зменшення потенщійних екологічних ризиків [20]. Цей принцип згадується в Національній стратегії управління відходами в Україні до 2030 року, схваленій розпорядженням Кабінету Міністрів України від 08.11.2017 р. № 820-р [21], та проєкті закону України від 04.06.2020 р. № 2207-1-д про управління відходами [22]. Попри всю екологічну значущість принципу наближеності, застосовувати його в Донецькій і Луганській областях потрібно із застереженнями. 
Міркуваннями наближеності до джерел утворення відходів недоцільно керуватися щодо зон, які прилягають до лінії розмежування та перебувають під загрозою ураження внаслідок ведення бойових дій. Об'єкти поводження 3 відходами мають бути максимально віддалені від таких зон (звісно, з огляду на принцип розумності). Ризики ймовірного пошкодження об'єктів поводження з відходами значно перевищують ризики, зумовлені транспортуванням відходів на білыші відстані. Прикладом є хвостосховище фенольного заводу (розташоване поблизу лініі розмежування біля міста Торецьк Донецької області), де зберігаються небезпечні хімічні відходи. У червні 2018 р. хвостосховище було пошкоджено через обстріли [23], що загрожувало забрудненням річки Кривий Торець і джерел водопостачання всієї області.

Важливим інструментом відновлення та підтримання екологічного добробуту міст на постконфліктних територіях є екологічний моніторинг, заснований на використанні сучасних методів і технологій. У законодавстві під екологічним моніторингом (моніторингом довкілля) розуміється система спостережень, збирання, оброблення, передавання, збереження та аналізу інформації про стан довкілля, а також прогнозування його змін і розроблення науково обгрунтованих рекомендацій для прийняття ефективних рішень про запобігання негативним змінам стану довкілля та дотримання вимог екологічної безпеки [24]. Нормативноправову основу цього виду моніторингу складають Закон України «Про охорону навколишнього природного середовища» (ст. 22), постанови Кабінету Міністрів України від 30.03.1998 р. № 391 «Про затвердження Положення про державну систему моніторингу довкілля» (визначає мету, принципи, завдання, суб'єктів та об'єкти моніторингу), від 19.09.2018 р. № 758 «Про затвердження Порядку здійснення державного моніторингу вод», від 14.08.2019 р. № 827 «Деякі питання здійснення державного моніторингу в галузі охорони атмосферного повітря» та інші нормативно-правові акти.

У Законі України «Про Основні засади (стратегію) державної екологічної політики України на період до 2030 року» та в наукових джерелах стан системи державного екологічного моніторингу характеризується як незадовільний [9; 25, с. 229]. Головними причинами неефективності цієї системи є недосконалість правового забезпечення, низький рівень координації діяльності суб'єктів моніторингу, слабке фінансування та застаріла технічна база. Фахівці справедливо зауважують на необхідності розроблення стратегії реформування державної системи моніторингу довкілля на основі інтеграції ії об'єктових, відомчих і регіональних складових, запровадження та використання сучасних геоінформаційних і комунікаційних технологій для автоматизації процесів збирання, оброблення й аналізу результатів спостережень [26, с. 97].

Не менш важливо активізувати регулярні спостереження за всіма складовими довкілля в зоні конфлікту на сході України із систематичним використанням даних дистанційного зондування Землі [11, с. 72; 5, с. 283]. Останнім часом з' являється все більше досліджень, присвячених космічному моніторингу полігонів побутових відходів, лісів, ділянок видобутку бурштину та інших об'єктів. Спостерігається прогрес і на практиці. 
Наприклад, Державна екологічна інспекція України обіцяє незабаром використовувати космічні технології для моніторингу довкілля та фіксації екологічних правопорушень [27]. А за допомогою супутникових знімків було легше виявляти та локалізувати лісові пожежі на Луганщині в липні 2020 р. [28].

Законодавство поки що не забезпечує системного регулювання відносин у сфері екологічного моніторингу на основі космічних технологій, але містить окремі положення щодо їх використання.

Так Державна екологічна інспекція України має право, відповідно до закону, здійснювати фотографування, звукозапис, кіно- і відеозйомку, зокрема з літальних апаратів та із застосуванням космічних технологій, як допоміжний засіб для запобігання та розкриття порушень екологічного законодавства [29]. Одним із суб'єктів моніторингу довкілля є Державне космічне агентство України, яке здійснює такий моніторинг: стану територій за даними дистанційного зондування Землі; сейсмічної обстановки та інших геофізичних явищ на території України та всієї Земної кулі; радіаційної обстановки в пунктах дислокації підрозділів спеціального контролю; космічної обстановки в навколоземному просторі (визначення місця падіння космічних апаратів, ракетоносіїв та їх частин). Агентство надає всім заінтересованим суб'єктам моніторингу архівну та поточну інформацію з дистанційного зондування Землі, а також методичну і технічну допомогу щодо інтерпретації та використання аерокосмічних даних (п.8, 23 Положення про державну систему моніторингу довкілля) [24]. Нарешті, створення та функціонування системи моніторингу грунтів базується на використанні даних дистанщійного зондування, сучасних геоінформаційних технологій для геокодування в міжнародній системі координат із метою інтеграції, узагальнення та комплексного аналізу еколого-агрохімічної інформації (п.1.5 наказу Міністерства аграрної політики України від 26.02.2004 p. № 51 «Про затвердження Положення про моніторинг грунтів на землях сільськогосподарського призначення») [30].

Для забезпечення екологічного благополуччя міст на постконфліктних територіях доцільно уточнити принципи, завдання, об'єкти, питання взаємодії між суб'єктами та визначити інші особливості екологічного моніторингу на основі космічних технологій. Перевагою такого моніторингу є можливість охоплення ним (принаймні, частково) територій Донецької та Луганської областей, де органи влади Украӥни тимчасово не здійснюють свої повноваження (на актуальності цього завдання наголошує Закон України «Про Основні засади (стратегію) державної екологічної політики України на період до 2030 року»). Достовірні дані про екологічну обстановку на цих територіях можуть бути використані для зниження екологічних ризиків як на підконтрольній, так і непідконтрольній частинах обох областей.

Висновки. 3 початком бойових дій на сході України загострилися існуючі екологічні проблеми та з'явилися нові виклики, що вплинуло на зростання соціальної напруги, погіршення здоров'я, відтік місцевого населення в інші регіони та економічний занепад Донецької і Луганської областей. Отже, забезпечення екологічної безпеки, відновлення екологічної рівноваги пов'язано не лише з покращенням якості довкілля, але й соціальним та економічним відродженням міст на постконфліктних територіях. 
Насамперед, потребує реагування проблема накопичення на відповідних територіях значних обсягів небезпечних відходів. На сучасному етапі доступним шляхом іiі розв' язання є надання дотацій із державного та місцевих бюджетів на перевезення цих відходів до місць утилізації в інших регіонах.

Регіональна специфіка має враховуватися і при вдосконаленні законодавства про відходи на основі норм права СС. Принцип наближеності, закріплений у цьому праві, не може застосовуватися щодо зон реального чи потенційного ураження через бойові дії.

Ефективність екологічного управління на постконфліктних територіях можливо підвищити шляхом здійснення якісного моніторингу довкілля. На сьогодні це означає широке залучення космічних технологій. Особливості моніторингу довкілля на основі цих технологій необхідно предметно віддзеркалити в законодавстві.

У подальших дослідженнях доцільно зосередитися на проблемах вдосконалення правових засад екологічного контролю та обліку на постконфліктних територіях.

\section{Використані джерела:}

1. Про рішення Ради національної безпеки і оборони України від 14 вересня 2020 року «Про Стратегію національної безпеки України»: Указ Президента України від 14.09.2020 p. № 392/2020. Офріиійний вісник Украӥни. 2020. № 75. Ст. 2377.

2. Конституція України: Закон України від 28.06 .1996 р. № 254к/96-ВР. Відомості Верховної Ради Украйни. 1996. № 30. Ст. 141.

3. Про охорону навколишнього природного середовища: Закон України від 25.06. 1991 р. № 1264-ХІІ. Відомості Верховної Ради України. 1991. № 41. Ст. 547.

4. Про Рекомендації парламентських слухань на тему: «Пріоритети екологічної політики Верховної Ради України на наступні п'ять років»: Постанова Верховної Ради України від 14.01.2020 р. Голос Украӥни. 2020. № 18.

5. Личенко О. І. Проблеми екологічної безпеки тимчасово окупованих територій Донецької та Луганської областей та організаційно-правові засади їхнього вирішення. Вісник Національного університету «Львівська політехніка». Юридичні науки. 2016. № 845. С. 279-284.

6. Устименко В. А., Джабраілов Р. А. Економіко-правове забезпечення сталого розвитку Донбасу. Економіко-правові засоби стимулюючгг впливу на розвиток Донбасу: монографія / під заг. ред. В. А. Устименка. Київ : НАН України, Інститут економіко-правових досліджень, 2019. С. 7-22.

7. Зельдіна О. Р. Спеціальний режим господарювання як механізм вирішення соціально-економічних проблем Донбасу. Економіко-правові засоби стимулюючого впливу на розвиток Донбасу: монографія / під заг. ред. В. А. Устименка. Київ : НАН України, Інститут економіко-правових досліджень, 2019. С. 23-37.

8. Ілларіонов О. Ю. Стан та перспективи нормативного забезпечення ліквідації надзвичайних ситуацій на територіях закритих (затоплених) вугільних шахт. Об'єкти екологічного і суміжних галузей права: теоретичні та практичні аспекти в умовах сталого розвитку : матеріали Всеукр. наук.-практ. конф. (м. Київ, 29 листопада 2019 р.). Київ, 2019. С. 82-86.

9. Про Основні засади (стратегію) державної екологічної політики України на період до 2030 року: Закон України від 28.02.2019 р. № 2697-VIII. Відомості Верховної Ради України. 2019. № 16. Ст. 70. 
10. Звіт про стратегічну екологічну оцінку Державної програми розвитку транскордонного співробітництва на 2021-2027 роки. Міністерство розвитку громад та територій України. Київ, 2020. 67 с. URL : https:/ / www.minregion.gov.ua/wp-content/uploads/2020/ 09/zvit-seo.docx. (дата звернення: 01.12.2020)

11. Оцінка екологічної шкоди та пріоритети відновлення довкілля на сході України. Київ: BAITE, 2017. 88 c. URL : https://mepr.gov.ua/news/32004.html. (дата звернення: 01. 12.2020)

12. На території окупованого Донецька просів грунт на 20-25 сантиметрів. Укрінформ. 04.06.2018. URL : https://www.ukrinform.ua/rubric-regions/2473457-okupovanij-doneck-prosiv-na-2025-santimetriv-cernis.html. (дата звернення: 01.12.2020)

13. Прогноз економічного і соціального розвитку України на 2021-2023 роки. Міністерство розвитку економіки, торгівлі та сільського господарства України. 2020.113 с. URL : https:/ / www.me.gov.ua/Files/GetFile?lang=uk-UA\&fileId=68afc88a-c642-4f3c-95c9-ed5a9c6 546а6. (дата звернення: 01.12.2020)

14. Про затвердження Державної цільової програми відновлення та розбудови миру в східних регіонах України: Постанова Кабінету Міністрів України від 13.12.2017 р. № 1071. Офіиійний Вісник Украӥни. 2018. № 6. Ст. 248.

15. Автоматизована система моніторингу довкілля у Донецькій області. Департамент екології та природних ресурсів Донецької обласної державної адміністрації. URL : http:/ /ecology.donoda.gov.ua/avtomatizovana-sistema-monitoringu-dovkillya-u-doneckij-oblasti/.(дата звернення: 01.12.2020)

16. Регіональна доповідь про стан навколишнього природного середовища в Луганській області у 2018 році. Луганська обласна державна адміністрація. 2019. 253 с. URL : https:/ / deis.menr.gov.ua/lib/files/rdlo2018.pdf. (дата звернення: 01.12.2020)

17. Статистичний збірник «Довкілля України за 2018 рік». Державна служба статистики України. Київ, 2019. 214 с. URL : http://www.ukrstat.gov.ua/druk/publicat/kat_u/ 2019/zb/11/Zb_dovk_2018.pdf. (дата звернення: 21.12.2020)

18. Про відходи: Закон України від 05.03.1998 р. № 187/98-ВР. Відомості Верховної Ради Украӥни. 1998. № 36-37. Ст. 242.

19. Про затвердження переліку видів діяльності, що належать до природоохоронних заходів: Постанова Кабінету Міністрів України від 17.09.1996 р. № 1147. Зібрання постанов Уряду Украӥни. 1996. № 18. Ст. 505.

20. Directive 2008/98/EC of the European Parliament and of the Council of 19 November 2008 on waste and repealing certain Directives. Official Journal of the European Union. 22.11.2008. $\mathrm{L} 312$

21. Про схвалення Національної стратегії управління відходами в Україні до 2030 року: Розпорядження Кабінету Міністрів України від 08.11.2017 p. № 820-p. Офінційний Bicник Украӥни. 2017. № 94. Ст. 2859.

22. Про управління відходами: проєкт закону України від 04.06.2020 р. № 2207-1-Д. URL : http:/ /w1.c1.rada.gov.ua/pls/zweb2/webproc34?id=\&pf3511=69033\&pf35401=528766. (дата звернення: 01.12.2020)

23. У Торецьку на Донеччині зафіксували руйнування дамби хвостосховища Новгородського фенольного заводу. Hromadske. URL: https://hromadske.ua/posts/na-donbasiposhkodzheno-skhovyshche-khimichnoho-zavodu-iz-270-tonamy-vidkhodiv-mintot. (дата звернення: 01.12.2020) 
24. Про затвердження Положення про державну систему моніторингу довкілля: Постанова Кабінету Міністрів України від 30.03.1998 р. № 391. Офіиіийний вісник Украӥни. 1998. № 13 .

25. Іванов С. В., Ляшенко В. І., Харазішвілі Ю. М., Кучеров А. В., Коритько Т. Ю. Локалізація та ліквідація наслідків катастрофи довкілля на Донбасі. Економічний вісник Донбасу. 2019. № 3 (57). С. 217-240.

26. Екологічний паспорт регіону. Луганська область. 2019. 100 с. URL : https:// deis. menr.gov.ua/lib/files/eplo2018.pdf. (дата звернення: 01.12.2020)

27. Держекоінспекція фіксуватиме екологічні порушення за допомогою аерокосмічної зйомки. Урядовий портал. 12.11.2020. URL : https://www.kmu.gov.ua/news/derzhekoinspekciya-fiksuvatime-ekologichni-porushennya-za-dopomogoyu-aerokosmichnoyi-zjomki. (дата звернення: 01.12.2020)

28. Лісові пожежі на Луганщині виявили та локалізували за допомогою супутникових знімків. Державне космічне агентство України. 10.07.2020. URL : https://www.nkau. gov.ua/ua/news/khronika-podii/1560-lisovi-pozhezhi-na-luganshchini-viyavili-ta-lokalizuva li-za-dopomogoyu-suputnikovikh-znimkiv. (дата звернення: 01.12.2020)

29. Про затвердження Положення про Державну екологічну інспекцію України: Постанова Кабінету Міністрів України від 19.04.2017 р. № 275. Офіиійний вісник Украӥни. 2017. №36. Ст. 1131.

30. Про затвердження Положення про моніторинг грунтів на землях сільскогосподарського призначення: Наказ Міністерства аграрної політики України від 26.02.2004 p. № 51. Офріиійний Вісник України. 2004. № 13. Ст. 922.

\section{References:}

1. Pro rishennia Rady natsionalnoi bezpeky i oborony Ukrainy vid 14 veresnia 2020 roku "Pro Stratehiiu natsionalnoi bezpeky Ukrainy": Ukaz Prezydenta Ukrainy vid 14.09.2020r. № 392/2020. (2020) Ofitsiinyi visnyk Ukrainy - Official Gazette of Ukraine, 75, art. 2377. [in Ukrainian].

2. Konstytutsiia Ukrainy: Zakon Ukrainy vid 28.06.1996 r. № 254k/96-VR. (1996) Vidomosti Verkhoonoi Rady Ukrainy - Official Bulletin of the Verkhoona Rada of Ukraine, 30, art. 141. [in Ukrainian].

3. Pro okhoronu navkolyshnoho pryrodnoho seredovyshcha: Zakon Ukrainy vid 25.06.1991 r. №1264-XII. (1991) Vidomosti Verkhoonoi Rady Ukrainy - Official Bulletin of the Verkhoona Rada of Ukraine, 41, art. 547. [in Ukrainian].

4. Pro Rekomendatsii parlamentskykh slukhan na temu: “Priorytety ekolohichnoi polityky Verkhovnoi Rady Ukrainy na nastupni p'iat rokiv": Postanova Verkhovnoi Rady Ukrainy vid 14.01.2020 r. (2020) Holos Ukrainy - Voice of Ukraine, 18. [in Ukrainian].

5. Lychenko, O. I. (2016) Problemy ekolohichnoi bezpeky tymchasovo okupovanykh terytorii Donetskoi ta Luhanskoi oblastei ta orhanizatsiino-pravovi zasady yikhnoho vyrishennia. Visnyk Natsionalnoho universytetu "Lvivska politekhnika". Yurydychni nauky - Bulletin of the National University "Lviv Polytechnic". Legal sciences, 845, 279-284. [in Ukrainian].

6. Ustymenko, V. A., Dzhabrailov, R. A. (2019) Ekonomiko-pravove zabezpechennia staloho rozvytku Donbasu. Ekonomiko-pravovi zasoby stymuliuiuchoho vplyou na rozvytok Donbasu: monohrafiia. V. A. Ustymenko (Ed.). Kyiv : NAN Ukrainy, Instytut ekonomiko-pravovykh doslidzhen, 7-22. [in Ukrainian].

7. Zeldina, O. R. (2019) Spetsialnyi rezhym hospodariuvannia yak mekhanizm vyrishennia sotsialno-ekonomichnykh problem Donbasu. Ekonomiko-pravovi zasoby stymuliuiuchoho vplyou na rozzytok Donbasu: monohrafiia. V. A. Ustymenko (Ed.). Kyiv : NAN Ukrainy, Instytut ekonomiko-pravovykh doslidzhen, 23-37. [in Ukrainian]. 
8. Illarionov, O. Yu. (2019) Stan ta perspektyvy normatyvnoho zabezpechennia likvidatsii nadzvychainykh sytuatsii na terytoriiakh zakrytykh (zatoplenykh) vuhilnykh shakht. $O b^{\prime} i e k t y$ ekolohichnoho $i$ sumizhnykh haluzei prava: teoretychni ta praktychni aspekty v umovakh staloho rozvytku: materialy Vseukr. nauk.-prakt. konf. ( $m$. Kyiv, 29 lystopada 2019 r.) - Objects of environmental and related branches of law: theoretical and practical aspects in the conditions of sustainable development: materials of the All-Ukrainian scientific and practical conference (Kyiv, November 29, 2019). Kyiv, 82-86. [in Ukrainian].

9. Pro Osnovni zasady (stratehiiu) derzhavnoi ekolohichnoi polityky Ukrainy na period do 2030 roku: Zakon Ukrainy vid 28.02.2019 r. № 2697-VIII. (2019) Vidomosti Verkhornoi Rady Ukrainy - Official Bulletin of the Verkhoona Rada of Ukraine, 16, art. 70. [in Ukrainian].

10. Zvit pro stratehichnu ekolohichnu otsinku Derzhavnoi prohramy rozvytku transkordonnoho spivrobitnytstva na 2021-2027 roky. (2020) Ministerstvo rozvytku hromad ta terytorii Ukrainy. Kyiv. N. p. URL : https://www.minregion.gov.ua/wp-content/uploads/2020/09/ zvit-seo.docx. [in Ukrainian].

11. Otsinka ekolohichnoi shkody ta priorytety vidnovlennia dovkillia na skhodi Ukrainy. Kyiv : VAITE. (2017) N. p. URL : https:/ / mepr.gov.ua/news/32004.html. [in Ukrainian].

12. Na terytorii okupovanoho Donetska prosiv grunt na 20-25 santymetriv. Ukrinform. $\mathrm{N}$. d. N. p. URL : https://www.ukrinform.ua/rubric-regions/2473457-okupovanij-doneck-prosivna-2025-santimetriv-cernis.html. [in Ukrainian].

13. Prohnoz ekonomichnoho i sotsialnoho rozvytku Ukrainy na 2021-2023 roky. (2020) Ministerstvo rozvytku ekonomiky, torhivli ta silskoho hospodarstva Ukrainy. URL : https:// www.me.gov.ua/Files/GetFile?lang=uk-UA\&fileId=68afc88a-c642-4f3c-95c9-ed5a9c6 546a6. [in Ukrainian].

14. Pro zatverdzhennia Derzhavnoi tsilovoi prohramy vidnovlennia ta rozbudovy myru v skhidnykh rehionakh Ukrainy: Postanova Kabinetu Ministriv Ukrainy vid 13.12.2017 r. № 1071. (2018) Ofitsiinyi visnyk Ukrainy - Official Gazette of Ukraine, 6, art. 248. [in Ukrainian].

15. Avtomatyzovana systema monitorynhu dovkillia u Donetskii oblasti. Departament ekolohii ta pryrodnykh resursiv Donetskoi oblasnoi derzhavnoi administratsii. URL : http://ecology.donoda.gov.ua/avtomatizovana-sistema-monitoringu-dovkillya-u-doneckij-oblasti/. [in Ukrainian].

16. Rehionalna dopovid pro stan navkolyshnoho pryrodnoho seredovyshcha v Luhanskii oblasti u 2018 rotsi. (2019) Luhanska oblasna derzhavna administratsiia. URL: https://deis. menr.gov.ua/lib/files/rdlo2018.pdf. [in Ukrainian].

17. Statystychnyi zbirnyk «Dovkillia Ukrainy za 2018 rik». (2019) Derzhavna sluzhba statystyky Ukrainy. Kyiv. URL : http://www.ukrstat.gov.ua/druk/publicat/kat_u/2019/zb/11/ Zb_dovk_2018.pdf. [in Ukrainian].

18. Pro vidkhody: Zakon Ukrainy vid 05.03.1998 r. № 187/98-VR. (1998) Vidomosti Verkhovnoi Rady Ukrainy - Official Bulletin of the Verkhovna Rada of Ukraine, 36-37, art. 242. [in Ukrainian].

19. Pro zatverdzhennia pereliku vydiv diialnosti, shcho nalezhat do pryrodookhoronnykh zakhodiv: Postanova Kabinetu Ministriv Ukrainy vid 17.09.1996 r. № 1147. (1996) Zibrannia postanov Uriadu Ukrainy - Collection of resolutions of the Government of Ukraine, 18, art. 505. [in Ukrainian].

20. Directive 2008/98/EC of the European Parliament and of the Council of 19 November 2008 on waste and repealing certain Directives. (2008) Official Journal of the European Union, 312. [in English].

21. Pro skhvalennia Natsionalnoi stratehii upravlinnia vidkhodamy v Ukraini do 2030 roku: Rozporiadzhennia Kabinetu Ministriv Ukrainy vid 08.11.2017 r. № 820-r. (2017) Ofitsiinyi visnyk Ukrainy - Official Gazette of Ukraine, 94, art. 2859. [in Ukrainian]. 
22. Pro upravlinnia vidkhodamy: proiekt zakonu Ukrainy vid 04.06.2020 r. № 2207-1-d. UR L: http:/ /w1.c1.rada.gov.ua/pls/zweb2/webproc34?id=\&pf3511=69033\&pf35401=528766. [in Ukrainian].

23. U Toretsku na Donechchyni zafiksuvaly ruinuvannia damby khvostoskhovyshcha Novhorodskoho fenolnoho zavodu. Hromadske. URL : https://hromadske.ua/posts/na-donbasi-poshkodzheno-skhovyshche-khimichnoho-zavodu-iz-270-tonamy-vidkhodiv-mintot. [in Ukrainian].

24. Pro zatverdzhennia Polozhennia pro derzhavnu systemu monitorynhu dovkillia: Postanova Kabinetu Ministriv Ukrainy vid 30.03.1998 r. № 391. (1998) Ofitsiinyi visnyk Ukrainy Official Gazette of Ukraine, 13. [in Ukrainian].

25. Ivanov, S. V., Liashenko, V. I., Kharazishvili, Yu. M., Kucherov, A. V., Korytko, T. Yu. (2019) Lokalizatsiia ta likvidatsiia naslidkiv katastrofy dovkillia na Donbasi. Ekonomichnyi visnyk Donbasu - Economic Bulletin of Donbass, 3(57), 217-240. [in Ukrainian].

26. Ekolohichnyi pasport rehionu. Luhanska oblast. (2019). URL : https://deis. menr. gov.ua/lib/files/eplo2018.pdf. [in Ukrainian].

27. Derzhekoinspektsiia fiksuvatyme ekolohichni porushennia za dopomohoiuaerokosmichnoi ziomky. Uriadovyi portal. URL : https://www.kmu.gov.ua/news/derzhekoinspekciya-fiksuvatime-ekologichni-porushennya-za-dopomogoyu-aerokosmichnoyi-zjomki. [in Ukrainian].

28. Lisovi pozhezhi na Luhanshchyni vyiavyly ta lokalizuvaly za dopomohoiu suputnykovykh znimkiv. Derzhavne kosmichne ahentstvo Ukrainy. URL : https://www.nkau.gov. ua/ua/news/khronika-podii/1560-lisovi-pozhezhi-na-luganshchini-viyavili-ta-lokalizuvali-zadopomogoyu-suputnikovikh-znimkiv. [in Ukrainian].

29. Pro zatverdzhennia Polozhennia pro Derzhavnu ekolohichnu inspektsiiu Ukrainy: Postanova Kabinetu Ministriv Ukrainy vid 19.04.2017 r. № 275. (2017) Ofitsiinyi visnyk Ukrainy Official Gazette of Ukraine, 36, art. 1131. [in Ukrainian].

30. Pro zatverdzhennia Polozhennia pro monitorynh gruntiv na zemliakh silskohospodarskoho pryznachennia: Nakaz Ministerstva ahrarnoi polityky Ukrainy vid 26. 02.2004 r. № 51 . (2004) Ofitsiinyi visnyk Ukrainy - Official Gazette of Ukraine, 13, art. 922. [in Ukrainian].

Стаття надійшла до редколегї 01.12.2020

Трегуб А. А.,

кандидат юридических наук, младший научный сотрудник отдела хозяйственно-правовых исследований проблем экономической безопасности Института экономико-правовых исследований имени В. К. Мамутова НАН Украины (г. Киев, Украина)

\section{ПРАВОВОЕ ОБЕСПЕЧЕНИЕ ЭКОЛОГИЧЕСКОГО ВОССТАНОВЛЕНИЯ ГОРОДОВ НА ПОСТКОНФЛИКТНЫХ ТЕРРИТОРИЯХ}

Статья посвящена обоснованию предложений по совершенствованию правового обеспечения экологического восстановления городов на постконфликтных террито- 
риях. Для уменышения объемов накопления опасных отходов на этих территориях расходы на их перевозку к местам утилизации предложено временно финансировать за счет бюджетных средств.

Аргументировано, что применение принципа приближенности к источникам образования отходов требует ограничения относительно зон, прилегающих к линии разграничения и находящихся под угрозой поражения в результате боевых действий.

Предложено также определить особенности мониторинга окружающей среды на постконфликтных территориях с использованием космических технологий.

Ключевые слова: восстановление, постконфликтные территории, экологическая безопасность, отходы, мониторинг окружающей среды, космические технологии.

Trehub O.,

Candidate of Law, Junior Researcher of the Department of Economic and Legal Studies of Economic Security Problems of the V. Mamutov Institute of Economic and Legal Research of the NAS of Ukraine

(Kyiv, Ukraine)

\section{LEGAL SUPPORT OF ENVIRONMENTAL RESTORATION OF CITIES IN POST-CONFLICT AREAS}

The main purpose of the paper is to ground the propositions to improve the legal support of environmental restoration of cities in post-conflict areas.

Special attention is given to the problem of accumulation of large amounts of hazardous industrial waste. The paper offers to finance temporarily the costs of transportation of such waste to recovery sites at the expense of state and local budgets. At the same time, the costs of transportation of hazardous waste should be reimbursed to its owners (according to the polluter pays principle) after improving their financial situation and creating sufficient regional capacity for the recovery of the waste.

The paper states that the risks associated with hostilities in eastern Ukraine should be taken into account in the process of approximation of waste legislation to EU law. Primarily, it concerns the principle of proximity that enshrined in the Directive 2008/98/EC on waste (meaning that waste disposal and recovery should be as close as possible to the sources of its generation to reduce potential environmental risks). It is specified, that the principle of proximity should not be applied to areas adjacent to the line of demarcation and at risk of damage due to hostilities. Waste management facilities should be as far away from such areas as possible.

An important tool for restoring and maintaining the environmental well-being of cities in post-conflict areas is environmental monitoring. The paper shows that current legislation does not provide for systematic regulation of relations in the field of environmental monitoring based on space technologies. In view of this, it is suggested to clarify the principles, tasks, objects and to identify other features of the mentioned monitoring. Its data can be used to reduce environmental risks in both controlled and uncontrolled parts of Donetsk and Luhansk regions.

Keywords: restoration, post-conflict areas, environmental safety, waste, environmental monitoring, space technologies. 